\title{
The Role of Monarchy in the State-Building Process of Albania
}

\author{
Indrit Shtupi \\ PhD Candidate at the European University of Tirana \\ Cel: +355692926251/indritshtupi@yahoo.com \\ Arjan Vasjari \\ Lecturer at the European University of Tirana
}

Doi:10.5901/mjss.2013.v4n6p407

\begin{abstract}
The National Assembly on January of 1925 proclaimed Albania a republic and elected Zog President for a seven years period. On Saturday, the 1st September this amendments were approved by the Assembly, and Ahmet Zog proclaimed "Zog I, King of the Albanians" King Zog makes agreements with the Italians. These agreements provided that the Italian group should established the National Bank of Albania, which was to have the exclusive right of issuing paper currency, coining metal money and some other procedures. Within a month after the bank began the operations it was to organize the Company for the Economic Development of Albania state. The new Constitution of Monarchy put forward in December 1928 gave the unrestrictive legislative, judicial and executive powers, thus ensuring Zog's dominance. A rambling document of 234 articles the constitution stated that the Kingdom of Albania was a democratic, constitutional and hereditary monarchy.
\end{abstract}

Keywords: Monarchy, king, responsibility, territory, landowners

\section{Introduction}

After the First World War Albania lacked a single recognized government, and Albanians feared, with the justification, that Greece, Yugoslavia, and Italy would succeed in extinguishing Albanian's independence and carve up the country. Italian forces controlled Albanian political activity in the areas that occupied. The Serbs, who largely dictated Yugoslavia's foreign policy after World War I, strove to take over northern Albania; and Greeks sought to control southern Albania. A delegation sent by a postwar Albanian National Assembly that meet at Durres in December 1918 defended Albanian interests at the Paris Peace Conference, but the conference denied Albanian official representation. The National Assembly, anxious to keep Albania intact, expressed willingness to accept Italian protection and even an Italian prince, as a ruler so long as it would mean Albania did not lose territory (Zavalani, Z. 2007 pg. 288) Extraordinarily undeveloped, the Albania that emerged after World War I was some to something less than a million people divided into three major religious groups and two distinct classes: those people who owned land and claimed semi feudal privileges and those who did not. The landowners had always held the principal ruling posts in the country's central and southern regions, but many of them were steeped in the same Oriental conservatism that brought decay to the Ottoman Empire. The landing owning elite expected that they would continue to enjoy precedence. The country's peasants, however, were beginning to dispute the landed aristocracy's control. Muslims made up the majority of the landowning class as well as most of the pool of Ottoman-trained administrators and officials. Poor and remote, Albania remained decades behind the other Balkan countries in educational and social development. Illiteracy plagued almost the entire population. Despite the manager educational opportunities, literature flourished in Albania between the two world wars. Independence also brought changes to religious life in Albania. The ecumenical patriarch of Constantinople recognized the autocephaly of the Albania Orthodox Church after a meeting of the country's. Albania Orthodox congregations in Berat in August 1922. The most energetic reformers in Albania came from the orthodox population who wanted to see Albania move quickly away from its Muslim, Turkish past, during which Christians made up the underclass (Konica,F. 1999 pg. 94). Albania's conservative Sunni Muslim community broke its last ties with Constantinople in 1923, formally declaring that there had been no caliph. History always expects for figures coming out of obscurity and passiveness by playing a decisive role for their country. And this was the case for the Zog and his Monarchy. 


\section{Historical Background on the eve of Zog power coming}

Both Noli and Zog were the most competitive representatives for the power in Albania. After the First World War the first elections in Albania were held in April 1921. Noli and Zog held high posts on the government of Popular party in December of 1921. In December of 1922 Zog took the offices of both premier and minister of interior. He allied with the Conservative forces. He used the police and forceful measures to put through his desires, and his links were obviously with the beys and landowners. The progressive elements of his party pressed for Agrarian Reform. Noli and others with these opinions left the Popular party and formed an opposition organization. The elections of 1923 gave Zog only a plurality. After one month he resigned in favor of Shefqet Verlaci. The opposition it is not contended with the policy of new government (Jelavich, J. 1983 pg. 180). The opportunity came with the murder of Avni Rustemi, who was a reform leader. The opposition accused Zog for the murder of Avni Rustemi. The movement reached such proportions that the government fell and Zog fled to Yugoslavia and Noli came in power with his government. But acting in autocratic and unconstitutional manner, the new government was discredited from the start. One of the first acts of the Noli administration was to set up a political court, which sentenced several leaders of the previous government to death, in their absence, and ordered their properties to be confiscated. Zog himself had also decided that the moment had come to overthrow Noli (Vickers, M 1995 pg. 114). On December 1924, having recruited a mercenary force, which included Russian members of general Wrangle's refugee army, Zogu and around five hundred of his Mati tribesmen crossed from Yugoslavia into Albania. On Christmas eve he entered with his army to Tirana and Noli and his supporters fled to Italy. On January of 1925 the rump of National Assembly proclaimed Albania a republic and elected Zog President for a seven years period. The Parliament quickly adopted a new Constitution that granted Zog dictatorial powers, that allowed him to appoint and to dismiss ministers and he has the right for veto legislation. Having consolidated his position within Albania, Zog looked abroad for economic assistance in order to develop his country and to reinforce his regime (Traian Stoianovich.\&L.S.Stavrianos 1958 pg. 721). Once back in power, Zog had to deal with the states, Yugoslavia and Italy. Who had been so dangerous in the past. Belgrade expected repayment in the form of territory and influence in Tirana. It is certain that Zog premised Belgrade frontier concessions before the invasion, but once in power the Albanian leader continued to press Albanian's own territorial claims and was largely successful in resisting this pressure. In a territorial settlement made in July 1925 the Albania government handed-over Saint Naum on lake Ohrid, the border dispute was thus ended for the present. Relations with Italy involved other questions. One reason was that the Italy appeared at the time to be a less dangerous power to lean upon than Yugoslavia. The Serbs traditionally wanted a small Albania, while the Italians in the face of new Yugoslavia state, normally would prefer as large and as strong an Albanian state as possible. The Albanian's natural economic ties were with Italy, two thirds of her trade being with that country. There Albania received massive economic assistance from Italy and of course, accepted political interference. The economic penetration was paralleled by increasing the Italian political domination (Pollo, S.\&Puto, A 2000 pg. 111). In November 1926 the two states signed a pact of friendship. In this agreement the Italian government promised to protect the political and the territorial status quo in Albania. Zog's position was thus in effect guaranteed (Zavalani, T. 2007 .pg.. 309).

\section{The New Monarchy another perspective for Albania}

To continue his political aims for a successive Albanian Monarchy and being doubtful for the level of his political support, Zog decides to take some more promoting steps; he called for a new cabinet of ministers namely:

\begin{tabular}{|l|l|}
\hline Name & Official Job \\
\hline Hiqmet Delvina & President of the Council of Ministers and Minister off Justice \\
Kotcho Kota & Minister of the Interior \\
Elias Vrioni & Minister of the Foreign Affair \\
Djafer Ypi & Minister of Education \\
Milto Tutulani & Minister of Finance and Minister of Agriculture \\
Salih Vucheterni & Ministers of Public Works \\
\hline
\end{tabular}

These persons were chosen for these jobs presumably based on Zog's account for their outstanding ability and energy (Omari, L. 1991 pg. 49). Shortly after the formation of the new Cabinet, the President issued a decree proclaiming that elections for a Constituent Assembly to meet at Tirana on the 25th August would be held during July and the first half of 
August. The Assembly was called to effect certain modifications of the Albanian Constitution, and it was freely rumoured that these modifications were rendered necessary by Ahmed Zogu's intention to increase the efficiency of Albanian Monarchy. This rumour gave rise to a wave of monarchical enthusiasm which seems to have been spontaneous, although the manner in which the principal enthusiasts organized demonstrations led to some doubts as to their entire spontaneity. Zog was called upon to accept the throne as the saviour of the nation by a grateful people. Meantime the Albanian Government approached certain Powers, and ascertained that the proposed change of status of the country would be recognized, provided it was acceptable toy the Albanian people (Joseph, J. 1990 pg. 519). On the 25th August the Constituent Assembly met under the Presidency of Pandeli Evangeli, was patriotism had ever been beyond question. On the same day the Assembly acclaimed the proposed change of the Constitution, and committee was appointed to draw up the necessary amendments. On Saturday, the 1st September this amendments were approved by the Assembly, and Ahmet Zog proclaimed "Zog I, King of the Albanians" King Zog makes agreements with the Italians. These agreements provided that the Italian group should established the National Bank of Albania, which was to have the exclusive right of issuing paper currency, coining metal money and some other procedures. Within a month after the bank began the operations it was to organize the Company for the Economic Development of Albania state. There is no doubt that Albania profited economically from these arrangements with Italy (Ciano, G. 1994) pg. 57). Mussolini makes the Albania his bridgehead to the Balkans and Italy controlled the country's finances and army (www.albanian.com/information/history/zog.html). Despite some economic measures, it is important to emphasize some organizative steps. So, Zog considered the illiteracy of his people and among them he tried to attract the intellectual elements working as ministers. Meanwhile he backed the opening of schools to influence the educational level of people. But Zog was aware that the Albanians ministers were not enough to carry out his policies, that's why on these circumstances and Italian interests, all the advisors of ministers were Italian. Consequently during the late 1920s and early 1930s, Tirana was gradually transformed from a dormant old Ottoman town into something resembling a capital city. Streets were widened and paved, as Italian architects redesigned the city. Much of the central area was completely rebuild. Much of the domestic state budget went on public buildings during Zog's reign. Tirana's new ministry buildings housed the large number of Italian advisors who worked on public projects and "supervised" the ministries. In order to extent his direct control throughout the entire country, Zog classed great emphasis on the construction of roads. These would aid not only trade but also the collection of taxes in previously in accessible areas. To accelerate a program of road building opened up the remote outlying valleys the abolition of banditry and blood feuds. In order to recruit labour, every male Albanian over the age 16 years was legally bound to give ten days free labour each year to the state. It was argued that the Zog was the first to establish nationality feelings in defending Albania as an entity as it actually was. Concretely, these steps are dealt within details in the following topic.

\section{Te role of monarchy and the activity of Zog during his Reigning period}

\subsection{The new Constitution and the State organization}

The new Constitution of Monarchy put forward in December 1928 gave the unrestrictive legislative, judicial and executive powers, thus ensuring Zog's dominance. A rambling document of 234 articles the constitution stated that the Kingdom of Albania was a democratic, constitutional and hereditary monarchy ("The Constitution of Monarchy" pg. 2). For the first time in Albania we don't have state religion in the articles of new constitution. The exercitations of all the religions were free in Albania. The principle of democracy with the article: all creeds were equal before the law "The Constitution of Monarchy" 28 December $1928 \mathrm{pg}$. 4) was another step for the democratization of life in Albania. All power was derived from the nation, and vested in the King and a unicameral parliament. With establishment of Monarchy we have a modern state organization. The State Authority was made from Legislative Authority (the parliament which was elected every 4 years). The Executor Authority was made from Authority of the King, the Council of Ministers and Juridical Authority with Courts of State. In the State Organization of Monarchy, we have for the first the establishment of Supreme Court of the State, which was created to judge the abuses of Ministers, Chairman, members of State Council, members of State's Council, members of Controller's Council and General Attorney, during their charge. Finances of state were controlled from Controller Council which in it is function was independent (Milo, P. 1992 pg. 195). Another very important organ was the Council of State, which was created to fulfill the recommendations of Constitution and the special laws. The obligations of State's Council were:

1- to prepare the Codes

2- to prepare and to review the drafts 
3- to give the decisions about the concessions and conventions

4- to execute the charges of special law and the law of the state

\subsection{Political and Administrative reforms}

In the 1935 Zog again give assurances of a reform program. In October a new ministry under Mehdi Frasheri was formed with the intention of introducing reforms in administrate. Some concessions were made, including the granting of more freedom to the press. The regime lasted only a year. In November 1936 a conservative government was back in control under Koco Kota.

At the same time the Italian penetration intensified. Italian advisors now held posts in the civilian administration as well as in the military and some Italian colonists had settled in the country. In foreign affairs Zog attempted to keep Italian influence under control as much as possible (Traian Stoianovich \&L.S.Stavrianos $1958 \mathrm{pg}$. 725). The election process continued to ensure that only candidates loyal to Zog stood a chance of victory. One hundred gold francs had to be paid to the municipality by every would be candidate before his name was listed (Zavalani, T $2007 \mathrm{pg}$. 327). Under the Zog the government was entrusted to a single chamber legislature under the control of Council of State. In relations to this it is worth pointing out of growing tendency in Zog's internal policies, which was reinforced by all the legal reforms made at the beginning of the monarchic period: he was trying to harmonize the interests of the great landowners with those of the better-of classes in the towns. The aim of the Monarchy was to enlarge the social basis, by making the beys and the nouveaux-riches the two main props of his policy. Politically, since he was a monarch, he didn't allow according to his law, the foundation and of any opposing political party.

\subsection{Juridical and Economical reforms}

The Juridical reforms were too much important for Albania because until in the end of World War I. The law, which was implemented, was the practice of Ottoman law and customs. The Monarchy of Zog reorganized completely the laws of the land. Also Zog's Monarchy adopted the Penal Code based in the western Italian model in the 1928, came into force and replaced the modified Ottoman Code formerly in use. Adapted the Civil Code patterned after the Napoleonic Code in the 1929. The equality between the men and women in the Civil Code eradicated definitively the Ottoman law. It passed the Chamber of Deputies, which assembled on the 1st March, unopposed, and the senate by a large majority. Opposition to the Code emanated chiefly from some Catholics who resented the recognition therein of marriage as a civil matter and the provision made for the divorce (Schevill,F.1966 pg. 45). The opposition to the divorce facilities provided for all Albanians subjects of whatever domination led to the failure of an attempt to negotiate a Concordat with the Vatican. Also adopted a Commercial Code modelled in the French. About the economical reforms the Monarchy made the Law for the Agrarian reform in April 1930, provided for the expropriation, with compensation, of one third of each bey's estate. The lands thus acquired were to be resold on easy terms to the peasants. Trade agreements were concluded with Greece and Yugoslavia. During much of the interwar period the Italians held most of the technical jobs in the Albanian economy. About $70 \%$ of Albanians exports went to Italy. Italian factories furnished about $40 \%$ of Albanian's import, and the Italian government paid for the rest (S.Pollo, A.Puto pg. 123). Agriculture was the principle economic activity, occupying at least $80 \%$ of the population. Much of the best lands held in large estates by great landowners, which included Moslem Beys, the Christian Churches, and the Moslem religious orders.

\section{The influence and consequences of the Monarchy as the first Albanian state upon the Albanian people}

\subsection{Zog a cause or consequence of Italian conquest}

Maintaining that Monarchy is a reassertion of Albania sovereignty, Zog shares with all those who rise to power the actuating force of ambition (www.geocities.com/burreonline/History.html). But ambition does not exclude patriotism. Zog's ambition has been rewarded by the crown of Albania, and it is but human nature that it should have been gratified. Is the throne of Albania the goal of his ambition, or does he aspire to a more enduring fame? Will he be content with a life of luxury and ease, squandering his country's resources - but of these there is as yet no indication - or does he aspire to the gratitude of his people? Is he a mere adventurer, or is he the greatest of Albanian patriots? The Italian conquest was provoked by both Zog's policy and Italian interests. Zog has been continuously accused as the main cause of Italian invasion, as a traitor who sold Albania to Italy. His claim is mostly maintained by Enverian historiography and Zog's 
opponents. Evidently, he had his share on that event. After Zog reassumed his power, he realized that a foreign support was necessary since Albania was too poor and backward. Consequently he signed some economical agreements, which were supposed and indeed influenced the economic development of Albania at the time. Also leading authoritarian regime and trying to secure defense from foreign power, Zog signed another agreement whereby Italy was to provide military support to Albania in case it was threatened. Gradually Italy was deeply, establishing her presence in Albania. Italy, on the other side, was the only foreign state to have direct interests in Albania. First, due to Albania strategical position, Italy viewed it as supportive element for a possible Balkan extension. Next, Italian interests laid on natural sources from which Italian Albanian companies were effectively profiting (Galeazzo Ciano, G. 1994 pg. 79). The signature of the Pact of Tirana raised a storm of indignation throughout Yugoslavia, although no grounds for a formal protest against it could be discovered. The Pact was equivalent to a declaration by Italy that she was prepared no longer to allow Yugoslavia, either officially or unofficially, to retard the progress of Albania towards stability and prosperity. In the circumstances it was natural that Yugoslavia should declare that Italy intended to pursue in Albania the policy, which she herself had endeavoured to pursue. That this accusation found much credence in Great Britain and elsewhere is likewise intelligible, since the Fascist regime in Italy is generally regarded as being almost as nefarious as the Soviet regime in Russia, and Fascist policy as imperialism unbridled. Finally, Italy found Albania on attracting and supporting place to accommodate at least 2000 Italian people. So, this mutual involvement led to Italian conquest Albania, which brought about considerable domestic issues.

\subsection{The influence and consequences of Zog's Monarchy}

The Monarchy of Zog was a conservative and authoritarian regime, the primary aim of which was the maintenance of stability and order. It was thus supported by the clan leaders and landowners, all of whom had vested interests in pressuring the status quo. Under the new administration the northern tribes were for the first time brought with in the control of the central government, though they were allowed to retain their traditional organizations, as in the past. Although the new Civil and Criminal Codes introduced by Zog were in theory applied everywhere, the unwritten Canun of Lek still prevailed in many parts (.Zavalani, T. 2007 pg 322) Although the northern districts were much neglected during Zog's rule, he retained the loyalty of the northern tribes partly by his outstanding as a tribal chieftain, and partly by appointing other chieftains to posts in the army. Nevertheless the Catholic Tribes remained less well disposed towards him then were the Muslims. Loyalty to the regime was fostered by a system of "pensions" and the salaries connected with the granting of the military titles. So to attract move population in his police forces Zog promised higher ranks to his officers than they actually had. Another think he did, was the disarmament of people (Ciano. G. 1994 pg. 68). By gathering arms avoided fighting between people and he was thought to be successful in diminishing blood feud (from one per week, to one per sixth weeks).Before occupation Zog managed to sign some effective agreements in economic and military fields. But in this case, despite these positive effects some agreements brought about as a final outcome of Zog policy the Italian occupation in Albania. Zog married a Hungarian countess, Geraldine Apponyi, hoping that an heir would strengthen the position of his monarchy. Another step he undertook was the diminishing illiteracy, which during that period was critical (85\% of population was illiterate). There were no universities in Albania except for elementary and high schools in the mane towns. This background was even worst in northern Albania if compared with southern Albania. During his reign, he compiled and implemented the law about the Agrarian Reform, but with unsuccessful results. In most of the cases this law remained in letter thus causing spread displeasure among peasants and great unpopularity on the part of Zog. Also he made many enemies by trying to eliminate them, instead of diplomatically trying to integrate them. This fact was one of the main causes that brought about his final down fall.

\section{Conclusions}

Zog, the son of Mati bey entered in the political sphere when Noli was in power. Noli defended pro western ideas meanwhile Zog defended the big landowners interests. So between Zog and Noli started a harsh fight. Noli profited from some domestic issues and held his government, which lasted only 6 months. Through the Yugoslav support Zog managed to bring the Noli government down and in December 1924 he seized in power. Immediately he held a Constitutional Assembly and proclaimed himself President for a period of 7 years. Fearing popularity he decides to build the Monarchy, which should bring more popularity. He's Monarchy represent for his people the creation of an organized state. His role was fundamental for providing his country with a modern Constitution, pro western State Organization and a laic state. Through Monarchy he reformed Judiciary, adapting the Civil Code, which was based in the French model, 
while the Penal and Commercial Codes were based on the Italian model. Zog adapted these Codes because the old Codes were based on the Ottoman law.

With the reform in Judiciary he wants to be a part of Western Europe (Because Albania was for 500 years a province of Ottoman Empire). He based the economic reforms on Italian support and led Administrative reforms to. Before Zog came in power Albania was the most backward state in Europe, but he made big changes in economy of Albania. It was a clever strategy to collaborate with the Italians in the economic field, because in that time the Albania it didn't have the support of Great Powers. On the other side his policy with Italy urged the latter to invade Albania. Although he tried to face up this invasion, it was too late, because Albania was by then under total Italian dependency. Regarding the Political reforms he didn't go ahead, because recognizing no political parties he created a totalitarian state. Consequently his reigning period influenced strongly the history of Albania. To my opinion one of his main merits was that through Albania state he increased the National sentiments by creating the first Albanian State he managed to establish a central government. Zog's Monarchy has some negative influences too. He failed to secure broad masses support, and here we remind that he didn't effectively apply the Land reform. By creating a totalitarian Regime he made 0 lot of opponents who threatened his position. This situation caused instability and it was partially due to his considerable lack of political inability, that the Italian invasion occurred.

\section{References}

Ciano, G. (1994)."The Diary of Count Ciano Albania 1937-1943"

Fisher, B. J. (1999). "King Zog and the Struggle for Stability in Albania".

Jelavich, B. (1983). "The History of the Balkans" Twentieth Century.

Konica, F. (1993). "Naim Frasheri".

Milo, P. (1992). "The History from 1920 until 1941 to Albania".

Omari ,L. (1991). "History through the Years".

Pollo, S. \& Puto, A. (2000). "The History of Albania from ancientness until now"

Schevill, F. (1966). "History of the Balkan Peninsula: From the Earliest Times to the Present Day".

Stoianovich, T.\& Stavrianos, L. S.(1958) "The Balkans since 1453".

Swire Joseph, S. (1950). "The Rise of Kingdom”.

Vickers, M. (1995). "The Albanians A Modern History"

Zavalani, T. (2007) "The History of Albania"

\section{Internet Sources}

www.albanian.com/information/history/zog.html

www.en.wikipedia.org/wiki/zog_of_Albania

www.goecities.com/spirit of Albania/king zog.html 